IMPERIAL COLLEGE

\section{Architecture of Discontent}

AFter six years of negotiations, Imperial College, London, has unilaterally called off its plans for a merger with the School of the Architectural Association. Lord Penney, rector of Imperial College, has said on behalf of the governors that the basis for a merger no longer exists but Mr John Lloyd, the principal of the school, claims that the governors acted with "a total lack of good faith" and says that he cannot approach Imperial College again. Talks had continued until the last moment, and the break seems to have been a complete surprise; the University Grants Committee had approved the merger, which was to be dependent on the raising of $£ 500,000$ by the Architectural Association for new buildings. The lease on the association's present accommodation expires in 1976.

Two explanations for the sudden decision are being aired. The first, and most widely favoured, turns on the question of student power. The school of the Architectural Association (AA) has a tradition of liberal student representation, and was founded by students in 1847. Further, it appoints staff only for short periods and does not provide the life tenure that a university would give. Both of these points go against the grain at Imperial College, where the students are already seeking more involvement in administration. The second view is that the decision was forced by an anti-interdisciplinary lobby, and the idea of a conflict between architectural and engineering interests was even raised in a letter to the Times (February 9) by Professor Colin Buchanan of the department of civil engineering at Imperial College.

The AA itself apparently gives priority to the first explanation, and its council resolved on Monday night that there was, in its opinion, "a fundamental conflict of educational objectives". So, too, do the students at Imperial College, according to the union president, $\mathrm{Mr}$ Piers Corbyn. On Tuesday more than five hundred of them, accompanied by members of the staff and some students from the AA, left a wreath at Lord Penney's home and a message in his office.

One of the AA's main objectives at the moment is to guarantee the future of its students, many of whom take five-year courses. Because its lease ends in 1976 it cannot yet offer a complete course to prospective students for this autumn. Since the school is privately owned and cannot afford to continue beyond then without outside help, it seems that its future probably lies within the state system. Discussions on Monday with Mr Gerald Fowler, Minister of State at the Department of Education and Science, were said to be encouraging, and the immediate aim has become the investigation of "every possible alternative" now that the Imperial College plans have fallen through. Meanwhile the AA's president, Miss Jane Drew, who is on a fund-raising tour in the United States, has an even more urgent task ahead of her.

In the midst of the debacle the governing body of Imperial College has published its report for 1968-69, which was completed too soon to say anything about the architectural crisis beyond noting simply that there was agreement in principle ever the merger. But other problems are revealed. The appeal for $£ 2$ million, launched last January to bring in funds for building and research (see Nature,221, 118; 1969), has made "steady, if disappointing progress", reaching $£ 400,000$ by July 31 , but with a better response from city financiers than from industry. Nearly all the money that has come in so far has been spent on providing or converting student houses. In spite of a forecast deficit, however, the college managed to reach a surplus of $£ 62,691$ by the end of the year, by enforcing a 6 per cent cut in expenditure. Present estimates for 1969-70 suggest a likely deficit of $£ 50,000$, mainly because of salary increases, and more cuts may be needed next year.

During the session there were 3,792 full time students, some 1,200 short of the figure that the University Grants Committee thinks the college can take when its site is fully developed. How this growth is to be directed over the coming decade is now occupying a steering committee under the chairmanship of the pro rector, Lord Jackson. The committee is asking the college's departments how they intend to expand, and hopes to report during the first half of 1970 on what might be done.

\section{COMPUTERS}

\section{ICL at the Select Committee}

THE spectre of IBM haunted the room at Westminster where the Select Committee on Science and Technology was taking evidence from International Computers Ltd last week, and it will no doubt loom over the rest of the hearings on the British computer industry. The managing director of ICL, Mr Arthur Humphreys, put his company's plight in a nutshell: "There is no problem in the computer business which would not be solved by the demise of IBM". But IBM cannot be exorcised by wishful thinking, and the subcommittee appointed by the Select Committee to carry out the investigation under the chairmanship of Mr Airey Neave wanted to know if anything more concrete could be done. Mr Humphreys and his colleagues made plain their feeling that the British Government could do more to help. For example, American computers have been ordered for the Army Pay Corps and for the Home Office crime-fighting system, and this was affecting the credibility of the ICL System- 4 in the market place. It is proving difficult to sell System-4-teething troubles have not helped-and most of the company's business will continue to come from the 1900 series. Another problem is the rapid turnover of senior staff, and with the forward-looking orders going to the United States there is not enough of the advanced work which encourages people to stay.

Little progress is being made in the talks on collaboration with Europe as a way of spreading the competition with IBM, Mr Eric Moonman of the sulcommittee pointed out, and he wondered whether the Industrial Reorganization Corporation or the government could do anything to help. This was clearly a sensitive point, chiefly because the Aigrain proposal to cooperate on a powerful computer was the only proposal set up by industry rather than by civil servants, and pride was forcing the industry to make another effort to get the project moving before calling for help. 